\title{
A novel plasmid pEA68 of Erwinia amylovora and the description of a new family of plasmids
}

\author{
Emadeldeen Ismail · Jochen Blom • Alain Bultreys • Milan Ivanović • Aleksa Obradović • \\ Joop van Doorn · Maria Bergsma-Vlami $\cdot$ Martine Maes $\cdot$ Anne Willems $\cdot$ Brion Duffy • \\ Virginia O. Stockwell · Theo H. M. Smits · Joanna Puławska
}

Received: 26 March 2014 / Revised: 31 July 2014 / Accepted: 9 August 2014 / Published online: 2 September 2014

(C) Springer-Verlag Berlin Heidelberg 2014

\begin{abstract}
Recent genome analysis of Erwinia amylovora, the causal agent of fire blight disease on Rosaceae, has shown that the chromosome is highly conserved among strains and that plasmids are the principal source of genomic diversity. A new circular plasmid, pEA68, was found in E. amylovora strain 692 (LMG 28361), isolated in Poland from Sorbus (mountain ash) with fire blight symptoms. Annotation of the 68,763-bp IncFIIatype plasmid revealed that it contains 79 predicted CDS,
\end{abstract}

Communicated by Erko Stackebrandt.

Electronic supplementary material The online version of this article (doi:10.1007/s00203-014-1028-5) contains supplementary material, which is available to authorized users.

\section{E. Ismail · J. Puławska $(\bowtie)$}

Research Institute of Horticulture, ul. Konstytucji 3 Maja 1/3, 96-100 Skierniewice, Poland

e-mail: joanna.pulawska@inhort.pl

\section{E. Ismail}

Genetics Department, Agriculture Faculty, University of Sohag,

Sohag, Egypt

J. Blom

Bioinformatics and Systems Biology, Justus-Liebig-University

Giessen, Giessen, Germany

\author{
A. Bultreys \\ Département Sciences du Vivant, Centre Wallon de Recherches \\ Agronomiques, Gembloux, Belgium
}

M. Ivanović · A. Obradović

Department of Plant Pathology, Faculty of Agriculture,

University of Belgrade, Belgrade, Serbia

J. van Doorn

Enza Zaden Seed Operations BV, Enkhuizen, The Netherlands among which two operons (tra, pil) are associated with mobility. The plasmid is maintained stably in E. amylovora and does not possess genes associated with antibiotic resistance or known virulence genes. Curing E. amylovora strain 692 of pEA68 did not influence its virulence in apple shoots nor amylovoran synthesis. Of 488 strains of E. amylovora from seventeen countries, pEA68 was only found in two additional strains from Belgium. Although the spread of pEA68 is currently limited to Europe, pEA68 comprises, together with pEA72 and pEA78 both found in North America, a new plasmid family that spans two continents.

Keywords Fire blight - Plasmid stability · Pathogenicity · Virulence $\cdot$ Amylovoran synthesis

\section{Bergsma-Vlami}

National Plant Protection Organization, Wageningen,

The Netherlands

M. Maes

Unit Plant Sciences-Crop Protection, Institute for Agricultural and Fisheries Research-ILVO, Merelbeke, Belgium

M. Maes $\cdot$ A. Willems

Laboratory of Microbiology, Department of Biochemistry and Microbiology, Faculty of Science, Ghent University, Ghent, Belgium

\section{B. Duffy $\cdot$ T. H. M. Smits}

Environmental Genomics and Systems Biology Research Group, Institute for Natural Resource Sciences, Zürich University of Applied Sciences, Wädenswil, Switzerland

V. O. Stockwell

Department of Botany and Plant Pathology, Oregon State University, Corvallis, OR, USA 


\section{Introduction}

The plant pathogenic enterobacterium Erwinia amylovora is considered to be homogeneous in terms of phenotypic and genetic features (reviewed by Puławska and Sobiczewski 2012). Recent comparative genomics studies confirmed that the chromosome of $E$. amylovora is highly conserved and has over $99 \%$ amino acid identity among all strains tested (Mann et al. 2013). The native plasmid pEA29 (Laurent et al. 1989; McGhee and Jones 2000) is, with rare exception, ubiquitous among isolates of E. amylovora. The size of pEA29 ranges from 27.6 to $34.9 \mathrm{~kb}$, and much of the diversity in size of pEA29 is found in the genotypically distinct group of strains of E. amylovora that infect Rubus spp. (Mann et al. 2013; McGhee et al. 2002). The diversity in the pan-genome of E. amylovora is associated primarily with plasmid loss and gain. Some strains lack pEA29 (Carey et al. 2011; Llop et al. 2006; Mohammadi et al. 2009), and strains with other plasmids have been isolated from orchards (reviewed by Llop et al. 2012).

Fire blight and E. amylovora were first described in North America in the late 1800s (Thomson 2000). Subsequently, fire blight and the pathogen were reported in the UK and the Middle East in the late 1950s (Lelliot 1959) and afterward on the Baltic coast of Poland in 1966 (Bonn and van der Zwet 2000). Strains isolated in Poland were found to be homogeneous in terms of phenotypic and genetic features (Puławska et al. 2006). Early detected strains were, as many other strains from Central Europe, classified to the Pt1 pattern based on PFGE analysis of genomic DNA digested with the endonuclease XbaI (Jock et al. 2002, 2013). In terms of plasmid content, all strains of the pathogen isolated and characterized in Poland possess pEA29 (Llop et al. 2011). In addition, about $6 \%$ of the strains from orchards in Poland harbored an acquired plasmid pEI70 previously described in several strains of $E$. amylovora in Europe (Llop et al. 2011).

Recently, fire blight was observed in areas of Poland without a history of the disease, and it was postulated that the inoculum source was possibly from imported plant material. We isolated E. amylovora from an imported from the Netherlands Sorbus sp. plant with the symptoms of fire blight. The isolate harbored pEA29 and an approximately $68-\mathrm{kb}$ plasmid. The objectives of our study were to describe the novel plasmid called pEA68, to test the influence of plasmid on the virulence of E. amylovora and to estimate the dispersion of the plasmid in a collection of isolates from different geographic origins, hosts and years. Additionally, comparative genomics indicate that this plasmid is a representative of a novel family of plasmids, which we designated the pEA68 family found in some strains of E. amylovora.

\section{Methods}

Growth conditions, plasmid isolation and analysis

E. amylovora strains were grown on nutrient agar with $5 \%$ (w/v) sucrose at $26{ }^{\circ} \mathrm{C}$. For plasmid isolation, 162 strains originating from Poland were grown in CIRCLEGROW ${ }^{\circledR}$ (MP Biochemicals) liquid medium and crude plasmid DNA was isolated with the method of Zhou et al. (1990). Isolated plasmid DNA was digested with BamHI, and restriction profiles were examined with gel electrophoresis (1\% agarose). Isolates with plasmids that yielded only single bands in BamHI restriction profiles, indicative of pEA29 presence alone, were digested with HindIII that has several restriction sites in pEA29, to confirm absence of additional plasmids or to find differences in pEA29 sequence.

\section{Sequencing and annotation of pEA68}

Plasmid DNA was isolated from E. amylovora strain 692 using the NucleoBond Xtra Midi kit (Macherey-Nagel, Düren, Germany), which allowed to obtain high-quality plasmid DNA and decrease contamination with chromosomal DNA. Plasmid DNA was sequenced on a GS Junior (454 Life Science) by the commercial service of Genomed S.A. (Warsaw, Poland). In total, 11,233 high-quality filtered sequence reads were generated. Read data were assembled using GS De Novo Assembler (454 Life Sciences), in silico gap closure was performed within the Lasergene Package (DNASTAR, Madison, WI, USA) and final assemblies were confirmed by realigning reads against the consensus assembly using NGen 2.0 (DNASTAR). Of the 10,691 aligned reads, 5,624 reads mapped to pEA68, 3,754 reads to pEA29, and 1,313 reads to the chromosome of the sequenced strain E. amylovora CFBP 1430 (Smits et al. 2010). This yielded an average coverage of $37.05 \times$ for pEA68 and $59.37 \times$ for pEA29. Both plasmid sequences reported in this study were completely assembled and circular.

Plasmid pEA68 was annotated using the gene prediction program Prodigal (Hyatt et al. 2010). Subsequently, the potential function of each predicted gene was assigned automatically using the GenDB annotation pipeline (Meyer et al. 2003). The resulting plasmid annotation was curated manually. Whole-plasmid comparisons were done using the progressive alignment option of the Mauve comparison software (version 2.0) (Darling et al. 2004). Routine sequence manipulations were completed using several subroutines of the Lasergene package (DNASTAR).

Biogeography of pEA68

The PCR primer pair (692-6F: 5'-CAGGTGGTCACCGCGA CGGAATA-3' and 692-6R: 5'-CCTGTGGAACACCGCCG 
Table 1 Number of strains per country tested for the presence of pEA68 with primer set 692-6F/692-6R

\begin{tabular}{llll}
\hline Country & $\begin{array}{l}\text { Number of } \\
\text { strains tested }\end{array}$ & $\begin{array}{l}\text { Number of strains } \\
\text { positive in PCR }\end{array}$ & $\begin{array}{l}\text { Strains positive in PCR with } \\
\text { primers 692-6F/692-6R }\end{array}$ \\
\hline Poland & 162 & 1 & 692 (LMG 28361) \\
Belgium & 130 & 2 & LMG 27893; LMG 27894 \\
The Netherlands & 48 & 0 & - \\
Serbia & 41 & 0 & - \\
USA & 31 & 0 & - \\
Bulgaria & 31 & 0 & - \\
Egypt & 11 & 0 & - \\
Hungary & 6 & 0 & - \\
United Kingdom & 5 & 0 & - \\
Algeria & 5 & 0 & - \\
Lithuania & 4 & 0 & - \\
Belarus & 4 & 0 & - \\
Spain & 3 & 0 & - \\
Italy & 3 & 0 & - \\
France & 2 & 0 & - \\
Greece & 1 & 0 & - \\
Israel & 1 & 3 & - \\
Total & 488 & &
\end{tabular}

AAGAACC-3') was designed to amplify a unique region of pEA68 (in EAMY692_p10021) and generate an 889 bp amplicon. Both primers were checked for homology to other sequences in the GenBank and EMBL databases using BlastN. The DNA amplification was performed in a total volume of $15 \mu \mathrm{l}$. The PCR mixture contained $1.5 \mu \mathrm{l}$ $10 \times$ DreamTaq $^{\mathrm{TM}}$ buffer (includes $20 \mathrm{mM} \mathrm{MgCl}_{2}$ ), $1 \mu \mathrm{l}$ dNTPs mixture (2 mM), $1 \mu$ l of each primer 692-6F and 6926R $(10 \mathrm{mM}), 0.07 \mu \mathrm{l}$ DreamTaq ${ }^{\mathrm{TM}}$ Green DNA Polymerase (5 U/ $\mu 1$ Thermo Scientific) and deionized $\mathrm{H}_{2} \mathrm{O}$. Cycling parameters were as follows: $94{ }^{\circ} \mathrm{C}$ for $3 \mathrm{~min}$., 34 cycles of $94{ }^{\circ} \mathrm{C}$ for $30 \mathrm{~s}, 67^{\circ} \mathrm{C}$ for $30 \mathrm{~s}, 72{ }^{\circ} \mathrm{C}$ for $45 \mathrm{~s}$ and final extension at $72{ }^{\circ} \mathrm{C}$ for $5 \mathrm{~min}$. The amplified products were electrophoretically separated in $1.5 \%(\mathrm{w} / \mathrm{v})$ agarose gel at $125 \mathrm{~V}$ for $2 \mathrm{~h}$ in $1 \times$ Tris-borate EDTA (TBE) buffer, $\mathrm{pH} 8.3$ and visualized with UV light after staining in ethidium bromide $(0.5 \mu \mathrm{g} / \mathrm{ml})$. The PCR detection assay was used to test 488 strains of E. amylovora from seventeen countries for the presence of pEA68. Tested strains originated from international or laboratory collections and were tested in laboratories in Poland, Belgium, the Netherlands, Serbia and the USA (Table 1; supplementary Table S1).

\section{Stability of pEA68}

Stability of pEA68 was tested in its native host $E$. amylovora strain 692 following the method of Foster et al. (2004) and Llop et al. (2011) in mmT broth medium (Falkenstein et al. 1989) in a serial transfer experiment. Briefly, strain 692 was cultured in $10 \mathrm{ml} \mathrm{mmT}$ broth at $26^{\circ} \mathrm{C}$ with agitation, and every $24 \mathrm{~h}, 100 \mu \mathrm{l}$ was transferred to fresh media. The transfers were performed over 20 consecutive days. After 20 days, the broth culture was spread on solidified mmT medium and 100 randomly selected colonies were tested for the presence of pEA68 with the PCR assay described above. Plasmids also were isolated from 20 colonies, digested with BamHI and examined with gel electrophoresis as described above.

Curing pEA68 from strain 692

A 3.95-kb region of pEA68 encompassing the origin of replication (ori) was amplified with the primer pair ORIF3 (5'-CTGTCGACACTGAAGGCAACCCATCGCTAACT-3') and ORIR3 (5'-CTCATATGGGACTTACCGGAAAACTG ACA- $3^{\prime}$ ), cloned into vector pGEM-T (Promega $\mathrm{GmbH}$ ) and transformed to chemically competent E. amylovora 692 cells. Strain 692 transformed with pGEM-T::ori ${ }_{692}$ was transferred several times on solidified LB medium (Bertani 1951) containing ampicillin until pEA68 was lost. The loss of pEA68 was confirmed by the PCR assay using primers 692-6F and 692-6R and RFLP analysis of isolated plasmids as described above. Loss of pGEM-T::ori ${ }_{692}$ from the cured 692 was achieved after several passages on LB medium without ampicillin and was confirmed by PCR using primers ORIF3 and ORIR3.

Determination of amylovoran concentration

Amylovoran production was measured in bacterial cultures with a quantitative turbidity assay using cetylpyrimidinium 
Table 2 Strains used for detailed analysis in this study

\begin{tabular}{lllll}
\hline Strain & Country & Host and year & Features & References \\
\hline $625 \mathrm{a}$ & Poland & P. communis, 2007 & pEA29, pEI70 & This study \\
650 & Poland & Crataegus, 1986 & pEA29 & (Puławska et al. 2006) \\
692 & Poland & Sorbus, 1997 & pEA29, pEA68 & This study \\
692 cured & - & - & pEA29, cured of pEA68 & This study \\
LMG 27893 & Belgium & Crataegus, 2002 & pEA29, pEA68, pEI70 & This study \\
LMG 27894 & Belgium & Cydonia, 2002 & pEA29, pEA68, pEI70 & This study \\
\hline
\end{tabular}

chloride as described by Wang et al. (2009). Measurements were taken 2 days post-inoculation on MBMA (Bellemann et al. 1994) medium supplemented with $1 \%$ sorbitol. The amylovoran concentration was determined for strains: 692, 692 cured of pEA68, 650, 625a, LMG 27983 and LMG 27984 by measuring $\mathrm{OD}_{600}$. The final concentration of amylovoran was normalized for a cell density of 1.0. Each strain was tested three times. The results were analyzed with ANOVA, and mean amylovoran concentration relative to cell density for each time point was separated with Tukey's test at $P=0.05$.

\section{Virulence assay}

Virulence of wild-type strain 692 and its derivative cured of pEA68 and other isolates with varying plasmid profiles (Table 2) was tested on shoots on one-year-old apple trees (cv. Idared) grown in a greenhouse. The tips of actively growing shoots were cut with scissors dipped in a suspension $\left(10^{7} \mathrm{cfu} / \mathrm{ml}\right)$ of a tested strain. Each strain was inoculated onto 15 replicate shoots. The virulence was measured 40 days post-inoculation and expressed as percentage of the length of shoot necrosis divided by the entire length of the shoot. The results were analyzed with ANOVA, and means were separated with Tukey's test at $P=0.05$.

Strain deposition number and nucleotide sequences

Strain 692 was deposited in LMG collection under the number LMG 28361. The sequences of pEA68 and pEA29 of E. amylovora strain 692 are available in the EBI database under accession numbers HG813238 and HG813239.

\section{Results and discussion}

Analysis of plasmid content of E. amylovora strains from Poland

With the view that the major factor influencing diversity in the E. amylovora pan-genome is the presence or absence of plasmids (Mann et al. 2013), we investigated a collection of strains from Poland for its plasmid content. Among 162 E. amylovora strains, we found three different plasmid

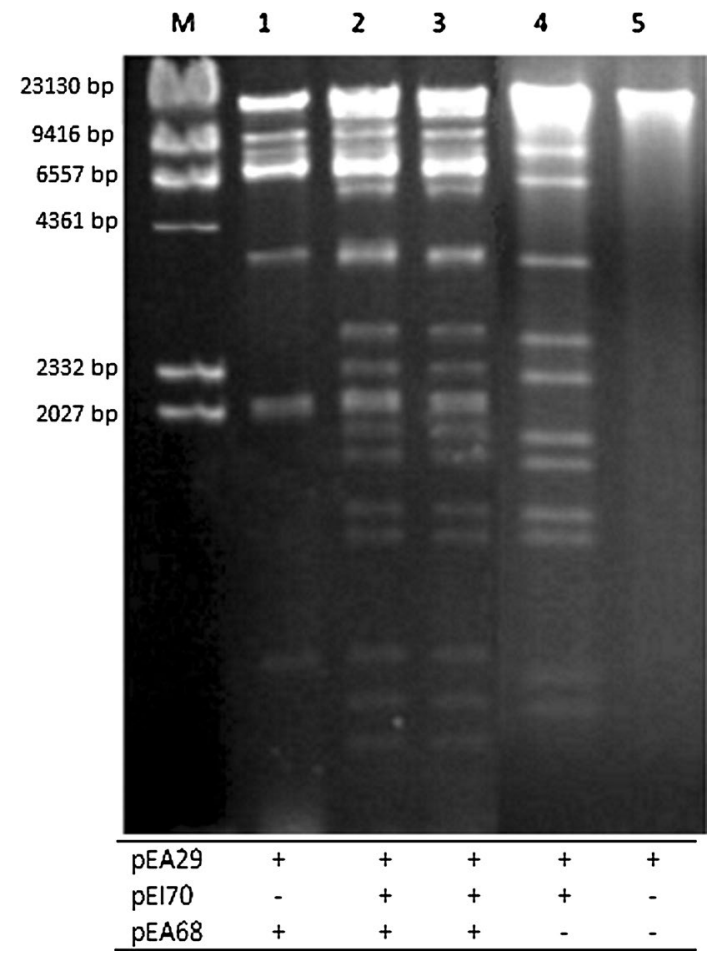

Fig. 1 The representative BamHI restriction patterns for different strains used in this study. $M$ : Marker $\lambda /$ HindIII; lane 1: E. amylovora strain 692 with plasmids pEA29 and pEA68; lane 2: strain LMG 27893 with plasmids pEA29, pEI70 and pEA68; lane 3: strain LMG 27894 with plasmids pEA29, pEI70 and pEA68; lane 4: strain 625a with plasmids pEA29 and pEI70; lane 5: strain 650 with pEA29

patterns and BamHI restriction profiles of plasmids (Fig. 1). The majority of tested strains $(92 \%)$ possessed only plasmid pEA29, giving a single band corresponding to the single BamHI restriction site in pEA29 (Fig. 1). RFLP analysis of plasmids isolated from strains harboring only pEA29 also had identical HindIII digestion patterns (data not shown). Twelve strains $(7.4 \%)$ possessed the plasmid pEI70 in addition to pEA29. The plasmid pEI70 was more frequently detected in this large collection of isolates of E. amylovora in Poland than previously reported (Llop et al. 2011). Only strain 692, isolated from a diseased shoot of a Sorbus sp. in Nowy Dwór in Poland in 1997, showed an atypical BamHI restriction pattern (Fig. 1). This indicated the presence of two plasmids, pEA29 and a novel plasmid designated pEA68. Strains 
without pEA29 or strains containing additional plasmids were not detected in the pathogen collection from Poland.

Sequencing and gene annotation of pEA68

The two plasmids isolated from strain 692 were sequenced using 454 sequencing and fully assembled. Plasmid pEA29 had a variant in the small sequence repeat (Schnabel and Jones 1998) also called VNTR-A (Bühlmann et al. 2014), which has been reported for pEA29 in European strains of E. amylovora (Mann et al. 2013; Smits et al. 2010). The sequence of the second plasmid showed that it is a circular plasmid of $68,763 \mathrm{bp}$ with a $\mathrm{G}+\mathrm{C}$ content of $60.39 \%$, what can be an indication of its foreign origin, because the $\mathrm{G}+\mathrm{C}$ content of the chromosome of E. amylovora is $53.60 \%$ (Smits et al. 2010). Based on the observed coverage for both plasmids, a ratio of $2: 1$ (pEA29:pEA68) was calculated. The copy number of pEA29 ranges between 1 and 5 copies/cell (Mann et al. 2013; Smits et al. 2010); therefore, we estimated that the copy number of pEA68 is between 1 and 2 copies/cell.

Annotation revealed that the pEA68 plasmid contains 79 predicted CDS with an IncFIla-type repA system for replication. The relaxase MobA belongs to the $\mathrm{MOB}_{\mathrm{P} 13}$ family (Garcillán-Barcia et al. 2009, 2011) and is of the same relaxase type as that of E. amylovora plasmid pEL60 (Foster et al. 2004) and related multidrug plasmids (Gołębiewski et al. 2007; Ho et al. 2011). However, plasmid pEA68 does not share any further homology to this group of plasmids. Among the CDS, a full set of tra genes encoding for conjugal transfer proteins and a pil region encoding a type IV secretion system are present. Plasmid maintenance is putatively enabled by the $s t b A B$ gene products but may also be influenced by the presence of a toxin-antitoxin system $(\mathrm{vag} C D)$. The $u m u C D$ gene products are putatively involved in error-prone repair of UV damage and mutations. The plasmid does not possess any known genes associated with antibiotic resistance or virulence nor any essential genes what was shown by successfully curing of pEA68 without any physiological effects (Table S2; Fig. 2).

Comparative sequence analysis revealing the pEA68 family of plasmids

Blast analysis of the sequence of pEA68 revealed that this plasmid is closely related to two plasmids that were found
Fig. 2 Circular representation of the E. amylovora plasmid pEA68. For genes without gene name, the locus tag number is given (EAMY692_p100xx). Identical colors represent proteins with a common function. Genes depicted in white code for hypothetical proteins or have a general function prediction only (color figure online)

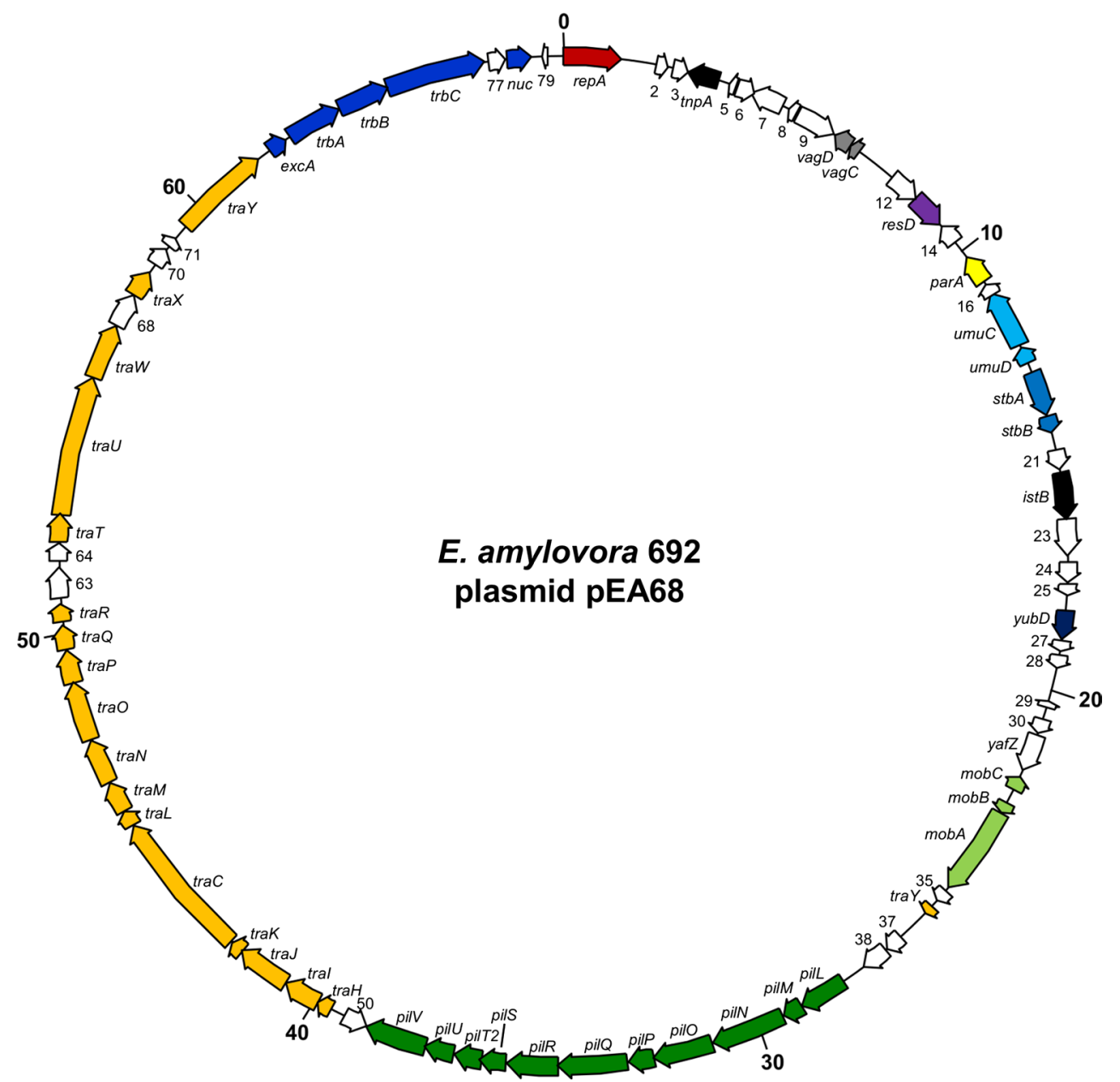




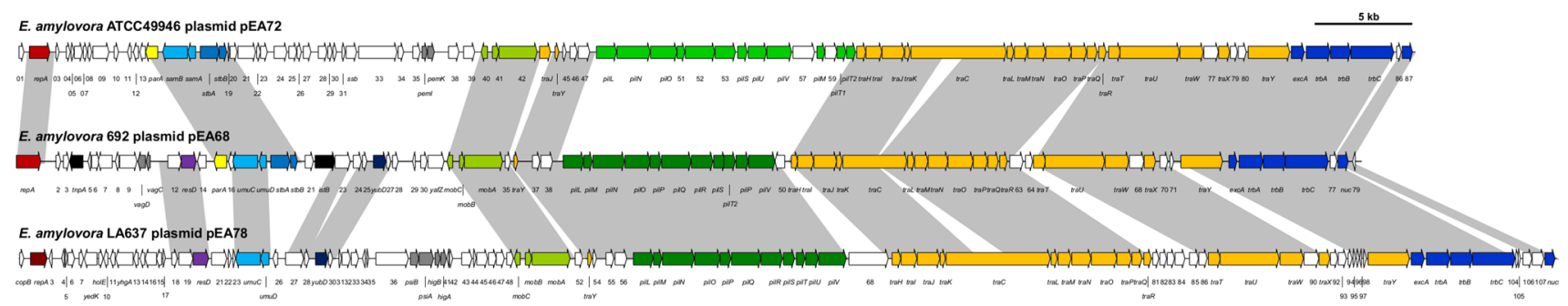

Fig. 3 Comparison of the plasmids of the pEA68 family. Top: $E$. amylovora plasmid pEA72; mid: E. amylovora 692 plasmid pEA68; bottom: E. amylovora LA637 plasmid pEA78. Grey shading indicate orthologous proteins. Identical colors represent proteins with a com-

in different E. amylovora strains, namely plasmid pEA72 of E. amylovora strain ATCC 49946 from the USA (GenBank acc. no. NC_013973) (Sebaihia et al. 2010) and plasmid pEA78 of strain LA637 from Mexico (GenBank acc. no. HG793099) (Smits et al. 2014) (Fig. 3). Levels of amino acid sequence identity between the plasmids pEA68, pEA72 and pEA78 are generally between 60 and $90 \%$ for related CDS. Overall, there were no other plasmids in the database that had gene synteny over the complete length of the plasmid, even though large-scale synteny was observed for two contigs in Pantoea ananatis strains PA4 and DAR76143, respectively (supplementary Fig. S1). Due to the incomplete status of the genome, these contigs were not included as members of the pEA68 family. We thus define the three E. amylovora plasmids as a novel plasmid family, having the same type of relaxase (Garcillán-Barcia et al. 2009, 2011), a similar conjugal transfer system and synteny over long stretches of the plasmid length, believed to have originated from a common ancestor.

The three plasmids share 35 CDS (Fig. 3). These CDS encompass mainly the mob, tra and trb gene clusters and the ити $C D$ genes. The pil gene cluster is conserved between pEA68 and pEA78, but is organized differently and with less sequence identity in pEA72. The repA region, the parA gene and the $s t b A B$ genes are only shared between pEA68 and pEA72, whereas pEA78 contains an IncFII repA gene with a lower identity to that of the other plasmids. Large regions with genes encoding various small proteins and remnants of transposases and resolvases between the repA gene and the mobABC gene cluster are divergent in all three plasmids, indicating that these regions are highly variable likely due to horizontal gene transfer. Because there is a larger overall synteny to each of the members of this family, we consider pEA68 the founder of this family.

\section{Stability of pEA68 in E. amylovora}

To determine whether pEA68 is maintained in E. amylovora strain 692 , the strain was cultured in $\mathrm{mmT}$ broth mon function. The pil genes of plasmid pEA72 have similar functions (as indicated by the same color), but have no orthology to the pil genes in the other two plasmids (color figure online)

for 20 days, with daily transfers to fresh media, and then spread on agar media. Plasmid pEA68 was detected by PCR in all 100 colonies tested. Plasmid profiles of 20 colonies showed that the BamHI patterns were identical as in the original E. amylovora strain 692. This indicates that the plasmids were not lost, and also neither plasmid integrated into chromosome or rearranged during continuous culture. We conclude that both pEA29 and pEA68 are highly stable in E. amylovora strain 692, although tra genes encoding for conjugal transfer proteins are present on pEA68 plasmid. The presence of genes involved in DNA transfer does not determine the low stability of plasmids as in case of other E. amylovora plasmids, e.g., pEL60 (Foster et al. 2004).

\section{Biogeography of pEA68}

In the view of the widespread distribution of plasmid pEI70 in Europe (Llop et al. 2011), a geographically diverse collection of E. amylovora strains from 13 European countries, Algeria, Egypt, Israel and the USA were tested for pEA68 (Table 1). For this purpose, primers were designed to target a gene encoding a hypothetical protein (locus tag EAMY692_p10021). On the basis of Blast $\mathrm{N}$ analysis, the newly designed primers, 692-6F and 692-6R, did not show $100 \%$ homology to any known DNA sequence. Of the 488 strains tested, pEA68 was found only in two additional strains of the pathogen from Belgium, LMG 27893 and LMG 27894 (Table 1). These two strains from Belgium carry three plasmids (pEA29, pEA68 and pEI70), as confirmed by PCR assays (Llop et al. 2000, 2011, this study) and by plasmid isolation and BamHI digestion (Fig. 1). Taking into consideration the fact that strain 692 was isolated form Sorbus imported from the Netherlands, there is the probability that the plant was infected already in the nursery and isolate 692 also origins from this region of Europe. In this case, all three strains possessing plasmid pEA68 would come from two neighboring countries-Belgium and the Netherlands. Generally, the results of pEA68 biogeography show that pEA68 was uncommon in strains 


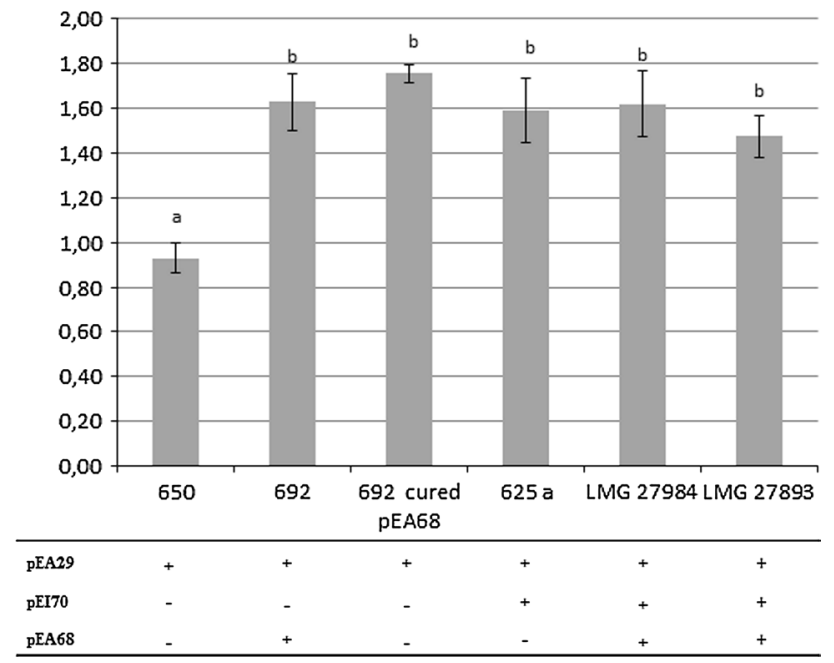

Fig. 4 Amylovoran production. Bacterial strains were grown in MBMA media with $1 \%$ sorbitol for 2 days at $28{ }^{\circ} \mathrm{C}$ with shaking. The quantity of amylovoran was measured with the cetylpyrimidinium chloride assay and normalized to a cell density of 1 . Data points represent means of three replicates. The vertical bars represent standard deviation. The data that do not differ significantly from one another are marked with the same letter

from Europe. Out of 440 European strains tested, it was found only in 3 of them $(0.68 \%)$. However, it cannot be excluded that this plasmid could be found in strains from other regions of Europe if more strains would be tested. Although the dispersal of pEA68 was confirmed currently in only two countries in Europe, the new plasmid family consisting of pEA68, pEA72 and pEA78 is distributed over two continents.

Influence of pEA68 on amylovoran production and virulence of E. amylovora

There were no statistically significant differences in amylovoran production nor virulence comparing the wild-type strain 692 and 692 cured of pEA68 (Figs. 4, 5). The virulence of strains, with and without pEA68 tested on shoots of apple "Idared," ranged from 61 to $100 \%$ of the shoot appearing necrotic at 40 days post-inoculation (Fig. 5). Considering all wild-type strains, there was no significant difference between strains with and strains without pEA68, except strain 650 (possessing only plasmid pEA29) which showed the lowest amylovoran production and the lowest virulence. These two features are strongly correlated, and amylovoran has been shown to be one of the most important pathogenicity factors of $E$. amylovora (Maes et al. 2001). We included strain 650, a low amylovoran-producing strain, as an internal control to test the differential sensitivity of the virulence assay. We conclude that the assay had sensitivity to distinguish virulence levels among strains and that the lower virulence and

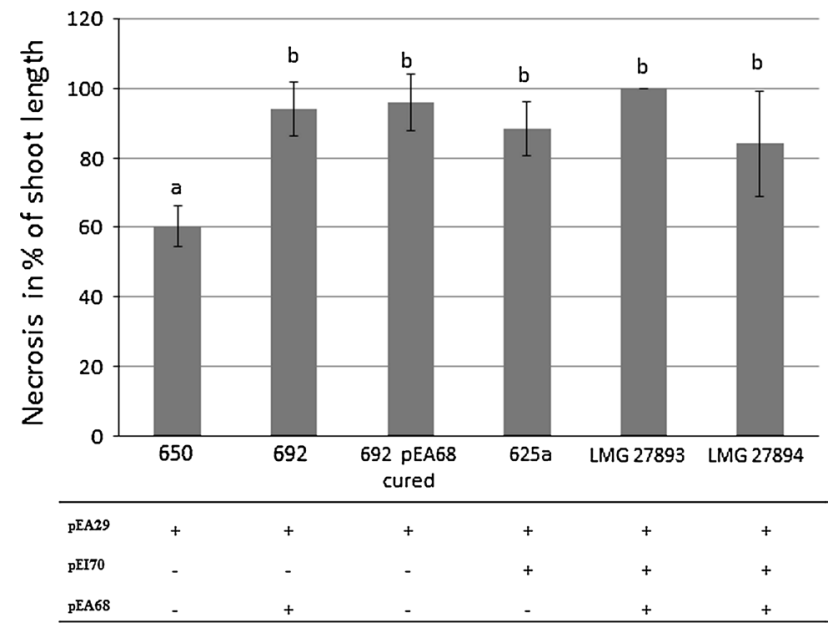

Fig. 5 Mean virulence rating of E. amylovora strains that differ in plasmid content. Each strain was inoculated to 15 replicate actively growing shoots of young "Idared" apple trees maintained in a greenhouse. Virulence was measured 40 days post-inoculation and it is expressed as a percent of the length of a shoot exhibiting necrosis divided by the entire length of shoot. Mean virulence ratings were separated with Tukey's test at a significance level of $P=0.05$. The data that do not differ significantly from one another are marked with the same letter. The vertical bars represent standard deviation

amylovoran production by strain 650 were due to other genetic factors, not related to plasmid content. Overall, we conclude that pEA68 has no direct effect on amylovoran synthesis (Fig. 4) or virulence of E. amylovora (Fig. 5) under the conditions tested.

\section{Conclusions}

Genomic analysis of the three plasmids pEA68, pEA72 and pEA78 identified a novel family of highly similar plasmids that we designate as the pEA68 family. Plasmid pEA68 is regarded as the base of this family, because this plasmid is the smallest one and also shares more CDS with each of the other plasmids individually. pEA68 did not influence virulence nor amylovoran synthesis of E. amylovora, and bioinformatics indicated that the two other members of the pEA68 plasmid family also were unlikely to impact pathogenesis (Sebaihia et al. 2010; Smits et al. 2014). These conclusions are similar to those of earlier studies that found that other acquired plasmids in E. amylovora (Foster et al. 2004; Powney et al. 2011) had no influence on virulence on apple and other rosaceous plants.

Acknowledgments We thank Jan van der Wolf (Plant Research International, Wageningen, The Netherlands), Svetoslav Bobev (Agricultural University, Plovdiv, Bulgaria), Said Sadallah (University of Skikda, Algeria), Anatoli Nikolaevich Evtushenkov (Belarusian State University, Minsk, Belarus), Alia Abed El-Baky Shoeib 
(Alexandria University, Egypt), Milda Vasinauskiene (Institute of Botany, Vilnius, Lithuania) and Maria López (IVIA, Valencia, Spain) for providing strains. Funding was provided by MARD (project HORhn8427/1/2013), Euphresco ERA-Net pilot project PhytFire (www.phytfire.org) and III 46008 (Ministry of Education, Science and Technological Development, Republic of Serbia).

Conflict of interest The authors declare that they have no conflict of interest.

\section{References}

Bellemann P, Bereswill S, Berger S, Geider K (1994) Visualization of capsule formation by Erwinia amylovora and assays to determine amylovoran synthesis. Int J Biol Macromol 16(6):290-296

Bertani G (1951) Studies on lysogenesis. 1. The mode of phage liberation by lysogenic Escherichia coli. J Bacteriol 62(3):293-300

Bonn GW, van der Zwet T (2000) Distribution and economic importance of fire blight. In: Vanneste JL (ed) Fire blight: the disease and its causative agent, Erwinia amylovora. CABI Publishing, Wallingford, pp 37-54

Bühlmann A, Dreo T, Rezzonico F, Pothier JF, Smits TH, Ravnikar M, Frey JE, Duffy B (2014) Phylogeography and population structure of the biologically invasive phytopathogen Erwinia amylovora inferred using minisatellites. Environ Microbiol 16:2112-2125

Carey AB, Pusey PL, Smith TJ, Loper JE, Stockwell VO (2011) Plasmid content of isolates of Erwinia amylovora from orchards in Washington and Oregon in the USA. Acta Hort 896:123-126

Darling ACE, Mau B, Blattner FR, Perna NT (2004) Mauve: multiple alignment of conserved genomic sequence with rearrangements. Genome Res 14:1394-1403

Falkenstein H, Zeller W, Geider K (1989) The 29 kb plasmid, common in strains of Erwinia amylovora, modulates development of fireblight symptoms. J Gen Microbiol 135:2643-2650

Foster GC, McGhee GC, Jones AL, Sundin GW (2004) Nucleotide sequences, genetic organization, and distribution of pEU30 and pEL60 from Erwinia amylovora. Appl Environ Microbiol 70:7539-7544

Garcillán-Barcia MP, Francia MV, de la Cruz F (2009) The diversity of conjugative relaxases and its application in plasmid classification. FEMS Microbiol Rev 33:657-687

Garcillán-Barcia MP, Alvarado A, de la Cruz F (2011) Identification of bacterial plasmids based on mobility and plasmid population biology. FEMS Microbiol Rev 35:936-956

Gołębiewski M, Kern-Zdanowicz I, Zienkiewicz M, Adamczyk M, Żylińska J, Baraniak A, Gniadkowski M, Bardowski J, Cegłowski $\mathrm{P}$ (2007) Complete nucleotide sequence of the pCTX-M3 plasmid and its involvement in spread of the extended-spectrum B-lactamase gene $b l a_{(\mathrm{CTX}-\mathrm{M}-3)}$. Antimicrob Agents Chemother 51:3789-3795

Ho PL, Lo WU, Yeung MK, Lin CH, Chow KH, Ang I, Tong AH, Bao JY, Lok S, Lo JY (2011) Complete sequencing of pNDMHK encoding NDM-1 carbapenemase from a multidrug-resistant Escherichia coli strain isolated in Hong Kong. PLoS One 6:e17989

Hyatt D, Chen G-L, LoCascio PF, Land ML, Larimer FW, Hauser LJ (2010) Prodigal: prokaryotic gene recognition and translation initiation site identification. BMC Bioinformatics 11:119

Jock S, Donat V, López MM, Bazzi C, Geider K (2002) Following spread of fire blight in Western, Central and Southern Europe by molecular differentiation of Erwinia amylovora strains with PFGE analysis. Environ Microbiol 4:106-114

Jock S, Wensing A, Pulawska J, Drenova N, Dreo T, Geider K (2013) Molecular analyses of Erwinia amylovora strains isolated in Russia, Poland, Slovenia and Austria describing further spread of fire blight in Europe. Microbiol Res 168:447-454
Laurent J, Barny M, Katoujansky A, Dufriche P, Vanneste JL (1989) Characterization of a ubiquitous plasmid in Erwinia amylovora. Mol Plant Microbe Interact 2:160-164

Lelliot RA (1959) Fire blight of pears in England. Agriculture 56:564-568

Llop P, Bonaterra A, Peñalver J, López MM (2000) Development of a highly sensitive nested-PCR procedure using a single closed tube for detection of Erwinia amylovora in asymptomatic plant material. Appl Environ Microbiol 66:2071-2078

Llop P, Donat V, López MM, Cabrefiga J, Ruz L, Montesinos E, Palomo JL, Rodriguez M (2006) An Erwinia amylovora strain without plasmid pEA29 isolated in a nursery from hawthorn. Acta Hort 704:431-437

Llop P, Cabrefiga J, Smits THM, Dreo T, Barbe S, Pulawska J, Bultreys A, Blom J, Duffy B, Montesinos E, López MM (2011) Erwinia amylovora novel plasmid pEI70: complete sequence, biogeography, and role in aggressiveness in the fire blight phytopathogen. PLoS One 6:e28651

Llop P, Barbé S, López MM (2012) Functions and origin of plasmids in Erwinia species that are pathogenic to or epiphytically associated with pome fruit trees. Trees Struct Funct 26:31-46

Maes M, Orye K, Bobev S, Devreese B, Van Beeumen J, De Bruyn A, Busson R, Herdewijn P, Morreel K, Messens E (2001) Influence of amylovoran production on virulence of Erwinia amylovora and a different amylovoran structure in E. amylovora isolates from Rubus. Eur J Plant Pathol 107:839-844

Mann RA, Smits THM, Bühlmann A, Blom J, Goesmann A, Frey JE, Plummer KM, Beer SV, Luck J, Duffy B, Rodoni B (2013) Comparative genomics of 12 strains of Erwinia amylovora identifies a pan-genome with a large conserved core. PLoS One $8(2): \mathrm{e} 55644$

McGhee GC, Jones AL (2000) Complete nucleotide sequence of ubiquitous plasmid pEA29 from Erwinia amylovora strain Ea88: gene organization and intraspecies variation. Appl Environ Microbiol 66:4897-4907

McGhee GC, Foster GC, Jones AL (2002) Genetic diversity among Erwinia amylovora's ubiquitous plasmid pEA29. Acta Hort 590:413-421

Meyer F, Goesmann A, McHardy AC, Bartels D, Bekel T, Clausen J, Kalinowski J, Linke B, Rupp O, Giegerich R, Pühler A (2003) GenDB - an open source genome annotation system for prokaryote genomes. Nucleic Acids Res 31:2187-2195

Mohammadi M, Moltmann E, Zeller W, Geider K (2009) Characterisation of naturally occurring Erwinia amylovora strains lacking the common plasmid pEA29 and their detection with real-time PCR. Eur J Plant Pathol 124:293-302

Powney R, Smits THM, Sawbridge T, Frey B, Blom J, Frey JE, Plummer KM, Beer SV, Luck J, Duffy B, Rodoni B (2011) Genome sequence of an Erwinia amylovora strain with pathogenicity restricted to Rubus plants. J Bacteriol 193:785-786

Puławska J, Sobiczewski P (2012) Phenotypic and genetic diversity of Erwinia amylovora: the causal agent of fire blight. Trees Struct Funct 26:3-12

Puławska J, Kielak K, Sobiczewski P (2006) Phenotypic and genetic diversity of selected Erwinia amylovora strains from Poland. Acta Hort 704:439-444

Schnabel EL, Jones AL (1998) Instability of a pEA29 marker in Erwinia amylovora previously used for strain classification. Plant Dis 82:1334-1336

Sebaihia M, Bocsanczy AM, Biehl BS, Quail MA, Perna NT, Glasner JD, DeClerck GA, Cartinhour S, Schneider DJ, Bentley SD, Parkhill J, Beer SV (2010) Complete genome sequence of the plant pathogen Erwinia amylovora strain ATCC 49946. J Bacteriol 192:2020-2021

Smits THM, Rezzonico F, Kamber T, Blom J, Goesmann A, Frey JE, Duffy B (2010) Complete genome sequence of the fire blight 
pathogen Erwinia amylovora CFBP 1430 and comparison to other Erwinia spp. Mol Plant Microbe Interact 23:384-393

Smits THM, Guerrero-Prieto VM, Hernández-Escarcega G, Blom J, Goesmann A, Rezzonico F, Duffy B, Stockwell VO (2014) Wholegenome sequencing of Erwinia amylovora strains from Mexico detects SNPs in rpsL conferring streptomycin resistance and in the avrRpt 2 effector altering host interactions. Genome Announc. http:// genomea.asm.org/content/2/1/e01229-13.full.pdf+html
Thomson SV (2000) Epidemiology of fire blight. In: Vanneste JL (ed) Fire blight: the disease and its causative agent, Erwinia amylovora. CABI Publishing, Wallingford, pp 9-36

Wang DP, Korban SS, Zhao YF (2009) The Rcs phosphorelay system is essential for pathogenicity in Erwinia amylovora. Mol Plant Pathol 10:277-290

Zhou C, Yang YJ, Jong AY (1990) Mini-prep in 10 minutes. Biotechniques 8:172-173 